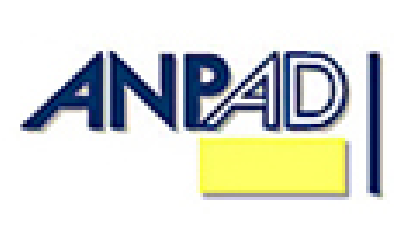

Available online at

http://www.anpad.org.br/bar

BAR, Curitiba, v. 5, n. 1, art. 4, p. 53-69,

Jan./Mar. 2008

\title{
The Modes of Provision of Prison Services in a Comparative Perspective
}

\author{
Sandro Cabral* \\ E-mail address: sandro.cabral@uol.com.br \\ Núcleo de Pós-Graduação em Administração (NPGA) - Universidade Federal da Bahia (UFBA) \\ Salvador, BA, Brazil \\ Paulo F. Azevedo \\ E-mail address: pfa@fgvsp.br \\ Escola de Economia de São Paulo (EESP) - Fundação Getúlio Vargas (FGV) \\ São Paulo, SP, Brazil
}

\begin{abstract}
This paper aims to compare the performance of two modes of provision of prison services: public, and with the participation of private companies. There are few empirical studies concerning the alternative modes of governance in this sector, which differs from other public utilities in that there is an absence of network externalities and scale economies. In addition, an understanding of informal institutions is crucial for the performance of the service provider, either public or private. In this paper, we build a comparative analysis of two case studies of similar correctional facilities, one public and the other outsourced to a private company under the supervision of civil servants (hybrid governance structure), both located in the same region of Brazil. We found that the privately operated facility has achieved better performance indicators (in terms of number of escapes, riots, deaths, assistance to inmates etc.) than the public facility, which in part refutes the arguments of Hart, Shleifer and Vishny (1997) against private participation in prison services. We conclude that the reasons for these differences are related to lower levels of administrative controls; to the presence of civil servants within the privately operated prison, which contributes to reducing information asymmetries; to greater incentives for the private operator: to monitor employees, to bypass local judiciary constraints and to fulfill contractual obligations.
\end{abstract}

Key words: prisons; privatization; public services.

Received 16 August 2006; received in revised form 11 August 2007.

Copyright (C) 2008 Brazilian Administration Review. All rights reserved, including rights for translation. Parts of this work may be quoted without prior knowledge on the condition that the source is identified.

*Corresponding author: Sandro Cabral

Núcleo de Pós-Graduação em Administração (NPGA), Universidade Federal da Bahia (UFBA), Av. Reitor Miguel Calmon, s/n, $3^{\circ}$ andar, Canela, Salvador/BA, Brazil, 41110-903. 


\section{INTRODUCTION}

Public or private? Although this is an essential question for policy makers, there are few studies that compare the relative performance of public and private modes for the provision of prison services. In addition, the majority of these studies focus only on the description of performance indicators without exploring the underlying reasons for performance differentials.

Furthermore, the prolific literature concerning the provision of public utilities focuses on sectors such as telecommunications, electricity and transport. Little is known about public and private modes for the provision of prison services in a comparative perspective.

Prisons are not influenced by network externalities nor by the existence of natural monopoly in some of the production phases, as other public utilities are. In addition, the correctional sector presents some features that deeply affect the design of public and private modes of organization, such as: a) the informal social norms that influence inmates' behavior, which might conflict with the formal rules; b) the risk of corruption of employees, as the occasional exchanges between inmates and custody agents can put the sector's performance indicators (riots, escapes, recidivism rates etc.) at risk; c) the influence of several social actors and formal institutions such as the judiciary, NGO's, politicians and civilian society, which can sometimes be contradictory. For these reasons monitoring and incentive schemes are particularly important in prison management - whether public or private - which requires an understanding of the above characteristics.

Although there are some studies that address the subject of private participation in prison management, they have basically been restricted to the areas of law (Affonso, 2002; D’Urso, 1996; Viggiano, 2002); philosophy (Minhoto, 2000) and sociology (Wacquant, 2001). Few studies focus on the economic aspects of the private provision of prison services, such as Dilulio $(1988,1996)$ - a critic of private participation -, Archeoembeault and Deis (1996) and Mitchell (2003) - who compare the two modes of coordination in a cost-benefit analysis -, and the seminal work of Hart et al. (1997), who analyze the subject under the Incomplete Contract Theory, although without an empirical analysis.

In an attempt to tackle this subject, we compare two different modes of the provision of prison service by using the cases of two similar facilities - one publicly managed and the other partially privately managed (hybrid mode of provision) ${ }^{(1)}$. Within the limits imposed by case studies, the paper also attempts to investigate the implications of the distinctive features of the prison service on the performance of public and hybrid management thereof. More abstractly, this work also analyzes the conflicts between the formal and informal norms prevailing in such institutions and their consequences on regulatory design.

The paper is organized as follows: the next section describes the main topics of the economic literature concerning the public versus private debate in the correctional sector. It also shows the possible modes of private participation in the prison service. The third section presents the case studies of two similar correctional facilities, one fully managed by the local government (publicly operated prison) and the other outsourced to a private company (privately operated prison), both located in the State of Bahia, Brazil. Some peculiarities of the correctional sector in Brazil are also presented. It must be added that the hybrid mode of provision adopted in Brazil differs from the U.S. model, where full privatization of prison services is permitted in some states. The fourth section briefly presents the comparative empirical evidence, while in the fifth section we try to understand and explain the differences observed between the two modes. The sixth section concludes the paper. 


\section{The Prison Service and the Public Versus Private Dilemma: the Contractual lens}

Private participation in prison services has been adopted in several countries along the reforms of public service widely known as New Public Management [NPM]. Basically, NPM focuses on efficiency matters in the public sector. In this vein, the managerial and economical literature can be useful in analyzing the modes of provision of correctional services. However, inasmuch as prisons services have distinctive features when compared to other public utilities, evaluation of their management mechanisms should take into account these distinctive characteristics.

The correctional sector presents some characteristics - highlighted by the New Institutional Economics literature - which have a great impact on regulatory design and on public and private performance. These include the presence of specific and non-deployable assets ${ }^{(2)}$ and the elevated number of beneficiaries of having dangerous criminals behind bars - which may be superior to the region's electorate (Levy \& Spiller, 1996). In addition, as in other public utilities, in correctional segment institutions, both formal and informal matter, and can influence the regulatory design and the sector's performance indicators. Particularly informal institutions within correctional facilities - i.e. the rules established by the inmates themselves - have an impact on prison performance and include the various modes of association among inmates, potential corruption of correctional agents and society's beliefs with regard to the treatment to be provided to condemned individuals, among others.

For these reasons, monitoring and incentive schemes are extremely important in the prison service. In this way, the three components for designing mechanisms of governance in public utilities mentioned by Shirley and Ménard (2002) in their analysis of water privatization in developing countries - can be applied to prisons: a) information asymmetry; b) structures of rewards and punishments; and, c) credible commitment.

In general, prison services are usually provided by the government, which implies hierarchical public provision or public governance. When comparing public and private modes of organization, Williamson (1999, p. 313) sustains that the main attributes of private governance are related to the intensity of incentives, lower levels of administrative controls and the use of the courts to solve occasional conflicts. On the other hand, in public modes of provision the incentives are weaker, the controls more rigid and the organization serves as its own court and last instance for appeal.

The residual control rights conferred to the agents, which depend on the formal allocation of rights and information asymmetry also shapes their incentives (Hart, 1995). Since it is very difficult to monitor all actions implemented by the agents, the delegation sometimes results in losses of control by the principal. In these cases, it is likely that imbalance between the formal and the real authority will occur, to use terminology of Aghion and Tirole (1997). These kinds of problems happen when the agents' pay-offs for implementing government policies are less than the pay-offs received for the implementation of alternative programs, and the possibilities of monitoring and enforcement are weak. Thus, incentives are required to reduce the harmful effects of information asymmetries.

In the past two decades private agents have entered the segment in response to an increase in the prison population and the increased expense thereof and the deterioration of prison housing and custody conditions as well as to social pressure to toughen the penal system at lower costs (Minhoto, 2000).

Despite the fact that the privatization or outsourcing of prison services has been spreading throughout the world, there are surprisingly few studies concerning private participation in the prison service in economics literature. Most work has focused on the cost and benefit analysis of the two different modes of governance (Archeoembeault \& Deis, 1996; Guppy, 2003; Mitchell, 2003). All of these works - built on quantitative data - confirm the superiority of private modes of governance in terms of cost effectiveness. However, these studies do not explain properly the reasons for such 
differences. In addition, Guppy (2003) and Mitchell (2003) demonstrate in their assumptions and conclusions a bias toward private participation.

With different conclusions and even without presenting empirical evidence, the seminal paper of Hart et al. (1997) is probably the most recognized work in economics literature that mentions the public versus private dilemma in prisons.

The authors adopt an incomplete contract view, where the private operator's residual control rights would contribute to reducing costs at the expense of quality. In order to improve quality, the private operator must incur both the costs of quality provision and the costs of influencing the government to accept changes (the government must agree to pay for improvements). Consequently, the private operator would have incentives to under-provide quality, which is socially inefficient. In addition, the benefits of managerial improvements in some cases may be inferior to the costs of reducing quality.

Another concern about private management expressed in Hart et al. (1997) is related to the fact that it would be very difficult to delineate contractually the level of force to be employed by a private operator. According to the authors, if corruption issues (mainly when choosing the company that will run the facility) appear to be a more severe problem than patronage, privatization should be carefully studied. For all these reasons the authors are skeptical about privately run prisons.

In the same light, Williamson (1999, p. 339) asserts that specialized physical assets and probity herein related to honesty and loyalty to government principles - would signal precaution even when the government retains ownership of the asset (the prison) and franchises out the operation. By analyzing the situation of juvenile correctional facilities in public versus private comparison, Bayer and Pozen (2005), corroborate the findings of Hart et al. (1997) by concluding that for-profit facilities lead to cost reductions at the expense of a statistically significant increase in recidivism. On the other hand, Lukemeyer and McCorkle (2006) in a extensive study covering 872 correctional facilities in US (state, federal and private) conclude that private prisons provide better services and more effectively control inmate assaults.

The above works fail to take into consideration the influence of formal and informal institutions and of alternative modes of provision in performance indicators in the correctional sector, such as shared management between civil servants and private operators. We expect to cover these aspects in our paper.

\section{Two Models of Private Governance in Prisons}

There are two distinctive models of private participation in the operation and management of prisons: the North-American and the French models (Araújo, 1995). In the North-American model, and in accordance with the specific laws of each state, private operators may become involved in all dimensions of the prison service, from the building of new facilities to full operation and management, which includes housing, assistance to inmates, monitoring and security activities. More than 30 NorthAmerican states have inmates in privately-run custody. In late 2004, over 150 facilities were managed by private operators in the United States, with 98,901 inmates representing $6.6 \%$ of the national inmate population (Harrison \& Beck, 2005) ${ }^{(3)}$. In general, private operators charge the government (their final customers) a daily rate for each inmate. In this way, their financial performance is dependent on the number of "man-days" they can clock up, so there are strong incentives to keep prisons at full occupancy rates.

Conversely, in the French model, the government remains responsible for maintaining, controlling and occasionally punishing the inmates. The private operator can build a correctional facility and provide inmates with only hostelry (food, clothes, hygiene etc.) and certain reinsertion services. Civil servants perform security and management duties. Private participation was introduced in France in 1987 in response to prison overcrowding. The original intention of the government was that the private sector would be able to deliver 13,000 new beds. Another 4000 places were added later. According to the Direction de l'Administration Pénitentiaire [DAP] (2005) there are 23 prisons under hybrid 
management (private and public agents) in France. Prison employees who are not part of the civil service only account for around $20 \%$ of staff (Lazerges, 1997).

Inspired by these two main references, several experiments were implemented throughout the world. In the United Kingdom, from 1995 nine PFI (Private Finance Initiative) contracts were signed. The private operators are responsible for building and operating the prison. There are also another 2 prisons built by public authorities that are managed by private operators. Around 7000 inmates are held in privately-managed facilities, which means almost $10 \%$ of the total prison population (National Audit Office [NAO], 2003). In Australia, the private experiments began in 1990. Australia has the highest proportion of inmates in full private prisons of any nation, at around 17\% (Roth, 2004).

In Brazil, the first experience of outsourcing the prison service took place in late 1999, along the lines of the French model. However, in contrast to France, Brazilian law allows correctional officers to be private employees. In the first quarter of 2006, there were 17 facilities managed by private companies in five different states, housing roughly $2 \%$ of the Brazilian inmate population, which in January 2006 was around 361,000 inmates. All contracts signed between private agents and public authorities are very similar. The state government is responsible for contracting a builder to build the prison. During or after construction the government promotes franchising bids to operate the facility. In this way, there are two separate contracts, one to build and another to operate. This practice has been termed unbundling (Hart, 2003). It is up to the private operator to provide all the necessary services to run the prison, which includes food, cleaning, health services, education, labor activities and inmate supervision. Due to legal constraints, the government remains responsible for external security and the management of the facility (warden) $)^{(4)}$. Therefore in the Brazilian model we can compare two modes of provision (or governance structures): hierarchy (public provision, in which the government conserves all decision and control rights) and hybrid (contract between state and a private firm for prison operation). Table 1 summarizes some characteristics of private participation in selected countries.

Table 1: Some Figures for Private Participation in Prison Services

\begin{tabular}{|l|c|c|c|l|}
\hline \multicolumn{1}{|c|}{ Country } & $\begin{array}{c}\text { Total Number of } \\
\text { Inamates }\end{array}$ & $\begin{array}{c}\text { Inmates / } \\
\mathbf{1 0 0 . 0 0 0} \\
\text { inhab. }\end{array}$ & $\begin{array}{c}\text { Private } \\
\text { Participation* } \\
\text { (\%) }\end{array}$ & \multicolumn{1}{|c|}{$\begin{array}{c}\text { Main Private } \\
\text { Groups }\end{array}$} \\
\hline Australia & 25.300 & 125 & $17 \%$ & $\begin{array}{l}\text { Group 4 (DK), } \\
\text { Sodehxo(FR) }\end{array}$ \\
\hline Brazil & 361.402 & 195 & $2 \%$ & $\begin{array}{l}\text { INAP (BR), } \\
\text { CONAP (BR), } \\
\text { Yumatã(BR) }\end{array}$ \\
\hline France & 59.246 & 96 & $29 \%$ & $\begin{array}{l}\text { Sodehxo (FR), } \\
\text { SIGES /SUEZ (FR) }\end{array}$ \\
\hline United Kingdom & 75.544 & 126 & $10 \%$ & $\begin{array}{l}\text { Group 4 (DK), } \\
\text { Sodehxo(FR), } \\
\text { SERCO (UK) }\end{array}$ \\
\hline United States & 2.135 .901 & 724 & $6 \%$ & $\begin{array}{l}\text { CCA (US), } \\
\text { Wackenhut (US) }\end{array}$ \\
\hline
\end{tabular}

Source: Prepared by the authors based on (Harrison \& Beck 2005; Departamento Penitenciário Nacional [DEPEN], 2006; Cour des Comptes, 2006; HM Prison Service, 2005; Roth, 2004)

* Australia, United Kingdom and United States employ full privatization

\section{Formal AND INFORMal InStitutions in Prison MANAGement}

Prisons are constrained by several formal and informal institutions. Those entities can deeply affect the performance indicators obtained (riots, escapes, recidivism rates, costs etc.). Therefore, we submit 
that the understanding of such variables is crucial in order to explain the differences observed in public and private governance modes.

\section{Formal Rules and Organizations}

In modern societies prisons play the following roles: to punish the transgressors of the law, to protect society from future crimes and to provide the necessary conditions to rehabilitate the individual for social life. The priority given to each of these topics can vary from country to country according to political issues and social choices.

In addition to the organizations in charge of the custody of penal inmates (prison itself), there are others involved in the custody process with regulatory and consultant roles. Among the judicial institutions involved there are judges and courts, public prosecutors (responsible for defense or judicial order and public interest) and public attorneys (responsible for the defense of the inmates who cannot afford a private lawyer). Although these actors are external to the prison, their acts impact the operation of the facilities. For instance, a judge can delay the process of releasing an inmate, which might generate a reaction from all the inmates.

The correctional segment is subject to pressure from political organizations, such as State Congress, and from politicians with varying interests: those who argue in favor of toughening the law as well as those who defend human rights. In addition, several external organizations such as NGO's involved with human rights have been denouncing the poor conditions of prisons throughout the world. According to Varella (1999), religious organizations also play a leading role in prison management, having pacifying effects on the turbulent internal environment as religion might eventually provide some personal comfort to the chaotic way of life inmates have behind bars.

The interaction among the several segments of public bureaucracy is remarkable when the government provides a service. In the case of the correctional segment, these relationships are not conflict free. For instance, some legal systems generate huge numbers of trials and appeals, each to be analyzed by a judge. In the Brazilian case, for example, a lack of administrative staff in courts and a relatively small number of public attorneys can be observed. All these elements make the workings of the legal system slow, mainly in developing countries ${ }^{(5)}$. As a result of those inefficiencies, it is not unusual to find cases of individuals being kept in prison awaiting trial or appeal.

Last but not the least, it must be added that overcrowding is one of main problems affecting prisons in most countries, both developed and developing ${ }^{(6)}$. The negative outcomes of overcrowding in the managerial performance indicators and in the prisoners' quality of life are evident.

\section{Informal Rules}

The social organization within the walls of the prisons and the corresponding social norms are common knowledge. The emergence and crystallization of inmate norms are associated to the codes of conduct of criminal activities and to the formal constraints imposed by the rule of law. Among them, distancing from social life, the suppression of formal support in exchanges with other inmates encompassing prohibition of the use of money -, and more generally the withholding of formal private property rights stand out.

There is a clear internal social hierarchy based mainly on each inmate's enforcement capabilities. At the upper level, one might find bank robbers and individuals accused of assault resulting in murder ${ }^{(7)}$. At the lower levels of the prison social pyramid are the rapists, squealers and ex-policemen, who are ostracized by their fellow inmates. For them, the sentence passed by the judge is minimal when compared to the tortures they will suffer at the hands of other inmates (Carvalho, 1998).

This particular social setting creates two codes of conduct: norms for living in shared cells and respect for visitors. As prison cells are small and shared, proximity and contact among the occupants 
are unavoidable. This forces the creation of basic rules to mitigate the costs of social interaction. Another component tacitly prescribed by inmates is common respect during visiting days, which includes respect for other inmates' relatives. Of course, punishment is applied to those who do not observe such rules.

The efficacy of the monitoring system relies on an understanding of inmate social order and norms of conduct. The work of prison agents and managers is essential in order to minimize the emergence of malign leadership among prisoners. Sometimes internal activities are carried out that lie on the verge of the legal and the ethical limits. In fact, there is a frequent use of squealers by the warden and security officers ${ }^{(8)}$. Based on their information, the managers can take action, such as carrying out detailed searches of the cells and inmates' belongings. Obviously, once discovered by other inmates, squealers suffer severe punishment, in compliance with existing social norms (jail laws).

Moreover, there is a dialogue between prison managers and inmate representatives on several aspects affecting operational decisions, such as food, allocation of prisoners to cells and galleries among other internal routines. In this case, knowledge of the inmates' social ordering is essential for managers as it enables them to recognize the legitimacy of their interlocutors and the possible consequences - such as riots and murders - resulting from conflict between management routines and the social norms of the inmates. In this regard, the codes of conduct of the prisoners deeply affect the performance indicators of the prison. In fact, in both modes of provision of prison services, the prisoners' behaviors inside the prison are the key variable that shapes the performance indicators. As a consequence, the way managers perceive, deal with and control inmates' behavior is an essential component of prison management.

In the next section, we present an empirical comparison between publicly and hybridly managed correctional facilities in Brazil. A summary of the results is also given.

\section{An Empirical Comparison: Public versus Hybrid Modes of Provision}

To obtain empirical data from the correctional sector is by no means an easy task. Amongst the reasons for such difficulties are the absence of consolidated data, the lack of standardized information, which impedes comparison on the same basis, and the barriers imposed by politicians and bureaucrats to release the information, i.e. to open up the black box of prison service.

In order to bypass some of these constraints, we compared two correctional facilities that share similar features, aiming to identify differences between the two governance structures. In this section we proceed to some methodological issues related to the discrete comparative analysis. After that, we present empirical evidence of the Brazilian experience of private participation in prison management on a comparative basis.

\section{Case Studies and Investigation Method}

This paper offers a comparative analysis between two correctional facilities of identical building size and design: The Teixeira de Freitas Penal Complex [CPTF] and The Penal Complex of Valença [CPV]. The former is entirely managed and operated by public employees. A private company in an operating franchise bidding contract operates the latter under public supervision. The five-year contract signed with the local government covers the full supply of all services to run the prison food, internal security, health care, legal aid and recreation activities for inmates. It also includes responsibility for paying water, electricity and communication bills, as well as building and vehicle maintenance. Apart from military policemen in charge of external security, there are three public employees in the unit: the warden, the assistant warden and the security chief. Both facilities are 
maximum security and can host 268 inmates with similar criminal backgrounds ${ }^{(9)}$. They are located in the State of Bahia in the Northeastern region of Brazil.

In the same approach as that of the work of Archeoembeault and Deis (1996) ${ }^{(10)}$, this paper aims to compare similar facilities in the same region in order identify the distinctive impacts of public and private governance. The choice of two prisons located in the same state also contributes to the control of institutional variables, which might vary in Brazil from one region to another. Inmates are allocated to prisons by geographic criteria, i.e. near their families in order to facilitate future social reinsertion. Inasmuch as both correctional facilities are located in rural regions of the same State, the geographic criteria do not pose any significant bias on the inmate population, allowing for a quasi-experiment.

The data used in the analysis were obtained from the Board of Directors of the Bahia State Penal Affairs Direction. Statistics for the years 2003 and 2004 and contracts between the government and private operators were made available. It could be argued that managers of public facilities have an incentive to misinform higher levels of public administration, enlarging problems in order to receive additional financial resources. Nevertheless some factors mitigate these effects of self-reporting. First, the data from the Board of Directors of the Bahia State Penal Affairsare subject to external auditing. Second, inasmuch their wages do not depend on performance indicators, prison managers (civil servants) have no incentive to misinform. Third, some performance indicators, such as riots and escapes, are publicly available. The problem of data reliability can also be extended to the privately operated facility. However, the propensity of misreporting from the private operator (for example, hiding information in order to keep the contract) is constrained by the civil servants present in the prison, who act as contract supervisors. We also used qualitative information collected in 18 interviews with prison managers, public officers, and members of the judiciary, politicians and union leaders and therefore the information obtained was double-checked by researchers who spoke with different actors.

The research method used is inspired by Shirley and Ménard (2002). It combines quantitative and qualitative analysis to understand the role of the following aspects in prison performance indicators: a) incentive factors (information asymmetry, rewards and punishment and credible commitment mechanisms); b) formal and informal institutions; and, c) management routines.

According to Brazilian law, in CPTF the public employees are only contracted through open competitive selection procedures. They have job security, meaning that they cannot be fired unless found guilty of serious misconduct, which must be verified by the Labor Courts. The dismissal process is slow and, owing to the possibility of appeals, can take years.

\section{Some Empirical Results}

We compared both facilities in terms of performance indicators in three dimensions: administrative, security and services to inmates. Although the facilities are similar in physical structure (same design) and capacity and inmates have similar criminal profiles, it is possible to observe some differences.

First, regarding the administrative indicators, the publicly managed prison employs $20 \%$ more staff to run the facility and reports absenteeism rates which are three times higher than the privately managed one. However, the salaries of the correctional officers in the privately operated unit were $60 \%$ lower than those of the civil servants in the public facility. While 2 employees were dismissed in the public facility over the period examined, in the privately run facility this number was 15 . The public prison spent 3 times more on water and electricity than the private company and invested $50 \%$ less than the private operator in the maintenance of the facility over the same period.

Second, concerning security indicators, results are also different. No escapes or escape attempts were recorded in the privately operated facility, whereas in the public there were 8 and 25 respectively. One riot occurred in CPV and none were recorded in the CPTF. However, the cost of this event - equivalent to US\$15,000 - was entirely assumed by the private company. The CPTF internal environment is more violent in comparison to CPV. During 2003 and 2004, the former registered 8 
assaults against employees, while the latter recorded none. In the same period the number of assaults among inmates was 12 times higher in the public facility.

The privately operated facility affords better services to inmates as compared to the similar public prison. According to data from the Board of Directors of the Bahia State Penal Affairs, the average number of medical appointments per inmate is 10 times lower in the publicly managed prison as compared to the number of medical appointments per inmate provided by the privately operated facility, which also offers $80 \%$ more psychological appointments per inmate when compared to CPTF. The public facility recorded only a slightly higher number of dentist visits (9\%). Regarding legal advice (an important source of riots and conflicts in Brazilian prisons), the number of appointments provided to inmates by the hybrid mode of provision of prison services is 20 times higher (10764 appointments versus 504 in the public prison during the two years). It must be added that the privately operated facility is responsible for providing legal counsel, and for that the company has its own lawyers. In CPTF, public attorneys are the only source of legal advice to inmates who cannot afford a lawyer. In short, performance indicators reveal better results for the hybrid mode of provision in this particular setting.

\section{Why SUCH DifFERENCES? SOME POSSIBLE REASONS}

As previously seen, the provision of prison services differs from traditional public utilities services since it does not require special care with market and coordination failures. On the other hand, monitoring and incentive mechanisms are more complex, inasmuch as they must respect the constraints given by inmates' social norms and the high likelihood of corruption of employees. We argue that the differences in terms of performance in the two modes of governance compared here are related to how public and private operators respond to this peculiar incentive system.

We present some key features below.

\section{Separation of Decision Rights}

Public, private and hybrid management of prison services differ in the way they allocate decision rights. Whereas under public mode of provision the prison director retains relevant decision-making rights ${ }^{(11)}$, in the hybrid model several operational activities such as hiring, training, firing and several management routines are delegated to the private company; however, the director (a civil servant) still retains responsibility for general management and security. This separation of decision rights between public and private representatives reduces the effect of asymmetric information between the private company and the government, and therefore affects the incentives provided to the operator (Brickley, Coles, \& Jarrel, 1997). The separation of decision rights restricts the warden's discretion and the private use of his/her information advantage. This solution is analogous to board models in corporate governance, in which board members are entitled to some decision rights - usually approval and ratification -whereas the CEO holds the right to propose and implement decisions (Becht, Bolton, \& Röell, 2002).

Whether working in prisons under the public or hybrid mode of provision, the agents (i.e. correctional officers) are keen to hide from the principal (i.e. the warden) information related to corruption arrangements or the use of violence against the inmates. The contract signed between the Bahia State government and the private operator of CPV has some clauses that allow the monitoring and reduction of the effects of information asymmetry ${ }^{(12)}$.

The separation of operation and management also facilitates the enforcement of sanctions in case of contractual non-compliance. In this case the warden of the unit (state representative) might not 
authorize payment to the private operator and therefore additional incentives for contract compliance are created.

\section{Incentives for Dealing with Legal System Inefficiencies}

There is reasonable consensus concerning the inefficiency of the Brazilian legal system and the resulting consequences on economic arrangements. Arida, Bacha and Lara-Rezende (2005) argue that the inexistence of a long term credit market in Brazil is caused by the poor guarantees the legal system offers creditors. Azevedo and Silva (2002) state that the greater proportion of stores owned in the Brazilian franchise sector compared to the number in North-America and France is due to the higher risks associated with the dispute solving mechanisms in Brazil. Zylbersztajn and Nadali (2003) assert that the location decisions in the agribusiness sector are sensitive to the way the regional courts judge contractual litigations between agricultural producers and food processors. Such inefficiencies are the consequence of the delays and uncertainties regarding court rulings. In the correctional sector, access to lawyers for inmates and the slow legal processes are critical points, as cases of benefit concessions, paroles and probations depend on judicial performance. Such factors are essential to cooling internal tensions.

The two prisons in this study present distinct standards of behavior due to differences in incentive structures and the formal constraints to which they are subject. The contract signed with the government foresees payment to the private operator for holding 268 inmates in a price cap contract. Thus, the private operator's profit margin increases as the number of prisoners under its responsibility decreases, which in turn leads the private operating company to have a vested interest in the efficiency of legal matters mainly related to appeals, probation and parole. In addition, as the costs of riots are charged to the private operator, the company is interested in judicial efficiency because this can mitigate some internal conflicts ${ }^{(13)}$. Overcrowding is also of concern to the CPV private operator. Very often courts issue new warrants for more prisoners, superior to a prison's capacity, which might generate operational deficits for the private company ${ }^{(14)}$.

In response to such incentives, the private operator gives lawyers who provide legal advice to inmates a bonus equivalent to $3 \%$ of their monthly salary for each release order obtained. As a result, privately operated facilities use higher numbers of legal advisors compared to the public governance facilities- which use public attorneys. The disparities are due to the fact that the number of public attorneys is insufficient to satisfy all the CPTF's needs. There is only one public attorney to cover all the needs of the town of Teixeira de Freitas, including the general needs of the entire population (120,000 inhabitants).

As regards the slow pace of the legal system, the privately operated facility has managed to bypass the constraints of lack of personnel in courts - one of the causes of this - by hiring three administrative assistants to support the operational activities of the court responsible for judging the cases at CPV. This has had a strong impact on the agility of the inmates' $\operatorname{cases}^{(15)}$, which is crucial for pacifying the internal environment of the prison. For the prison under public governance there are few, if any, chances of bypassing judicial restrictions.

In this field, one might compare the Brazilian mode of contracting the prison services with the North-American model. Whereas in Brazil the private operator has strong incentives to speed up inmates' releases as it receives a fixed amount regardless of the number of inmates, in the United States the private operators might be interested in criminals remaining in their custody as long as possible as they are paid on a man days basis. Thus, the way that the government specifies the contract is crucial for determining incentives for the private operator while it has to preserve the wider interests of society as a whole. 


\section{Monitoring and Punishment Mechanisms}

The incentives provided by hybrid governance for reducing riots and internal conflicts can also be verified in the monitoring efforts. As expressed by an executive of the private operator: “... when the government contracts me, it is because it wants to get rid of problems. So, my mission is to anticipate the problems and, if they occur, to solve them before the government officials become aware of them".

The outsourcer has also invested in improvements to improve prison security, such as installing electronic monitoring with video-cameras, refurbishment (including corrections to the original building plans, installing new bars, electric fences, additional gates, new cells for isolating dangerous criminals and a kennel). The social norms, which discipline inmate behavior, also make the monitoring schemes more complex. The benefits of a shrewd perception of the inmates' informal rules and how to articulate them with formal rules are not to be underestimated. In this case the accumulated daily experience with the inmates is much more important than anything learnt on initial training courses.

It is expected that some correctional officers in charge of directly supervising the inmates are susceptible to corruption. To minimize illicit arrangements, private operators perform private investigations into the conduct of their employees outside the facility, including socio-economic aspects of their lives in order to identify any relationships with criminals. As a result of this, 15 correctional officers have been dismissed in the last 2 years, as can be seen in section 4 . A private company executive recognizes that such dismissals were probably not all fair; however, as he says: "If in doubt, we fire". On the other hand, under traditional public provision, it would be impossible to carry out both systematic investigations and penalize those accused of some misconduct quickly.

Employment contract termination under the hybrid governance is a strong instrument which inhibits corruption of employees ${ }^{(16)}$, but it also means staff turnover costs that affect monitoring and incentive schemes. The number of dismissed employees in the privately operated facility has led to an increase in recruiting, training and dismissal costs and, more importantly, to a loss of specific human capital. Higher staff turnover is particularly costly in the privately run prison because of the loss of tacit knowledge of inmates' codes of conduct and social organization, which is hardly ever addressed in formal structured training sessions ${ }^{(17)}$. The consequences of such high turnover should be carefully analyzed from a long term perspective.

On the other hand, the publicly run correctional facility presents greater staff turnover at higher staff levels. Frequent escapes and claims of abuse have forced changes in the warden and other important managerial positions at the CPTF, unlike CPV, where greater stability at this level is encountered. Although the loss of the command position represents an individual cost, the warden of the publicly run prison does not have the same instruments to reduce riots and escapes as his colleague (who is also a civil servant) responsible for managing the prison with a private company operating it. On the one hand, the statute of the civil service inhibits stronger incentives for correctional officers and public attorneys while, on the other hand, the variation in income in case of dismissal is insignificant when compared to the variation in private company profit obtained through riots and reduction of internal conflict.

Because of the absence of contractual clauses which might penalize the private operator in the case of escapes, for instance, one could suppose complicity of the company with inmates to facilitate escapes. However, this is not the case when one looks at the number of escapes - none since the private operator has been in charge of the prison. Two factors can account for this: permanent monitoring by the public employees in management positions; and reputation concerns on the part of the private company, essential for obtaining new contracts in the future. Concerns with reputation may also explain the differences in the aggression indicators in the two prisons ${ }^{(18)}$. Since private participation is viewed with criticism by several actors in society (politicians, NGO's, labor unions 
etc.), the private participation in prison services is subjected to closer external monitoring, with the likely consequence of inducing extra efforts from the private operator to solve problems quickly.

\section{Optimum Level of Delegation}

One of the problems of the public mode of provision lies in the impossibility of formally delegating the power of decision to inferior administrative levels (delegating formal authority). Nevertheless, in order to assure that such formal rights constitute economic rights (Barzel, 1997), it is necessary to incur the costs of measuring the relevant information to exert and enforce those rights. Inasmuch as measurement costs of inferior administrative levels are significant, lower economic rights ${ }^{(19)}$ are allocated to custody agents in this mode. In contrast, the contract between the state and the private company delegates to the latter several formal rights, such as procurement and human resource policies, which may be subsequently delegated to inferior administrative levels.

As Hart (1995) argues, delegation can shape the incentives provided to agents. On the other hand, from the principal perspective, the delegation might help them to focus on core activities by reducing the number of actors to be coordinated. For instance, in the publicly managed prison herein analyzed, the warden must interact with other government agencies to provide health care, education and labor to inmates. Inasmuch as the Brazilian state bureaucracy does not present high standards of efficiency, such interactions unavoidably increase the frictions and the costs of transacting. If delegation occurs as we observe in the privately operated prison - the coordination and monitoring efforts decrease, since the number of interlocutors is reduced. In this way, at least in our case here, the flexibility provided by hybrid governance structure is positive.

According to the prison managers interviewed, regulatory institutions such as the National Penitentiary Department [DEPEN] and the State Council of Criminal and Penitentiary Policies [CPCP] have little influence on the activities of the units. In practice, this means more autonomy for each facility, which can contribute to misalignment between the policies designed at the macro level and their effective application in the day-to-day running of the facilities.

The controls imposed by the bureaucratic public administration have influenced the performance of the publicly managed prisons negatively. On the one hand, they are ambiguous and fail to inhibit misconduct by civil servants and, on the other, they are rigid in a way that makes operations less flexible, mainly in terms of hiring and procurement procedures. As observed in this study, the superior flexibility of the private operator is directly responsible for the better medical and psychological care provided to inmates ${ }^{(20)}$.

The misalignment between the administrative levels is particularly serious in the prison service where a meaningful part of the knowledge is tacit and specific and cannot be easily transferred to the upper managerial levels. In prisons under private governance (as in the United States) or hybrid governance (as in Brazil) there is the possibility of formally delegating decision rights to lower levels, as in the example of legal advice provided to inmates.

\section{CONCLUSION AND ProspeCts FOR FUtURE RESEARCH}

The comparative analysis of two case studies of similar correctional facilities - one fully managed by the local government and the other outsourced to a private company - provides some preliminary findings about the appropriate design of prison service provision. Empirical evidence shows that the privately operated facility (hybrid mode of provision) has achieved better performance indicators (in terms of costs, number of escapes, riots, deaths, etc.) than the publicly run facility. There are three main reasons that explain the superior performance of hybrid governance: a) the lower level of administrative controls; b) stronger incentives of the private operator to monitor employees, to bypass 
local judiciary constraints, and to fulfill contractual obligations; c) the separation of decision rights within the privately operated prison, which restricts the warden's discretion and the private use of his/her information advantage.

The provision of custody service is profoundly affected by the efficacy of the judiciary system. The timing of appeals, probation and parole represents a huge cost to prisons, often resulting in prisoners staying in custody longer than what would be legally appropriate. The delay in the expedition of release orders also accounts in part for riots and escapes, which are also costly to the prison service. One of the main differences between public and hybrid modes of provision herein analyzed are the incentives (monetary compensation) the latter provides to attorneys and the local judiciary (administrative support) to speed up release orders.

Also distinctive is the monitoring and punishment mechanisms in prison management. The management of prisons under hybrid governance uses contract termination as the main instrument to prevent corruption of custody agents. The higher turnover, on the other hand, limits the accumulation of specific human capital: knowledge about inmates' social norms. The trade-off between the risk of corruption and the gains from learning the inmate's social norms determine the optimal level of turnover.

The knowledge of inmates' social norms is also important when it comes to preventing riots and escapes. As this knowledge is mainly tacit and cannot be easily transferred to higher administrative levels, it is worth delegating formal authority to lower levels. Corroborating Williamson (1999), the lower levels of administrative controls gives the private operator more flexibility in the face of existing institutional constraints, mainly those related to legal matters and procurement procedures.

In addition, the case studies allow some comments on the work of Hart et al. (1997). For them, the difference between public and private property is related to the allocation of residual control rights. As the private operator retains some formal rights in several tasks, it does not have to wait for government approval to solve current issues, such as hiring physicians or psychologists and carrying out maintenance work. On the other hand, Hart et al. (1997) viewed private participation in prison management with a certain degree of skepticism because efforts to reduce costs would lead to deterioration in the quality of the service. In the same sense, Williamson (1999) also sustains that private participation in prison management due to probity concerns should signal precaution.

However, evidence from the cases studied suggests that the prison under hybrid governance - where prison management is shared between the state and a private company - has superior performance indicators in terms of administration, security and service to inmates.

We are aware that a case study is not enough to corroborate a theory, although it can refute some theoretical arguments. We are sure that these findings, as usual in case studies, may lack external validity. Thus, this paper has some limitations as it focuses mainly on economic aspects. Although, the economic aspects of prison services are almost neglected by the economic and administrative literature, we believe that this work is not an end in itself. For instance, sociological and ethical dimensions are key aspects in prison services and must also be incorporated into future developments. Furthermore, it was unfortunate that we were unable to obtain information about a critical issue in the correctional activities: the rates of recidivism. The non-availability of such information is a regular constraint faced by researchers in prison services, not only in Brazil but in other countries as well (along these lines, see Cabral \& Saussier, 2006; Lemgruber, 2000).

For future research, we intend to collect information on several prison units in different regions operated by private companies and entirely operated by public officials in order to test our hypothesis from the main conclusions drawn here in this case study. Although we do have information on certain performance indicators, the prison system does not collect data on inmates' social norms and evidence of corruption of custody agents, which would essential for empirical tests. This suggests that an extensive field study is necessary to give these findings some external validity. 


\section{NOTES}

${ }^{1}$ The expression mode of provision is equivalent to the concept of governance structure as used by scholars affiliated to the New Institutional Economics, such as Williamson (1985, 1999) and Ménard, C. (2004). The economics of hybrid organizations. Journal of Institutional and Theoretical Economics, 160(3), 1-32.

${ }^{2}$ In the same vein as Williamson (1985), prisons are a good example of specific assets, as they involve site, physical, human and dedicated specific assets.

${ }^{3}$ The incarceration rates in the USA are one of the highest of the world. As of the end of 2004, there were 2,135,901 inmates being held in local jails and in the state and federal correctional systems, which represents 724 inmates per 100,000 inhabitants. Furthermore, 6 million people are under the supervision of the correctional officers (including inmates, parolees and people on probation) (Harrison \& Beck, 2005). In Brazil, incarceration rates are 195 inmates per 100.000 inhabitants (DEPEN, 2006) and in France there are 96 (Cour des Comptes, 2006).

${ }^{4}$ The Brazilian contract model differs a little from the French one as, in the latter, the government still retains internal vigilance, medical care and legal assistance to inmates. Although inspired by the French experiment, in the Brazilian model more activities are delegated to the private sector.

${ }^{5}$ There are no consolidated statistics for the slowness of the Brazilian justice sector. We can get an idea about this by taking the example of Sao Paulo state (the most highly populated). From 1997 to 2002, a total of 939,327 lawsuits were filed at the local courts. In the same period, only 739,159 were judged (Source: Brazilian Justice National Database www.stf.gov.br/bndpj < Retrieved January, 20th 2006>).

${ }^{6}$ In France the overcrowding rates are $128 \%$ of the capacity rate (DAP, 2004). In Brazil the rate is 144\% (DEPEN, 2006), and in the UK 123.7\% (HM Prison Service, 2005).

${ }^{7}$ Normally inmate leaders have such a criminal profile (they are known as 'sheriffs'). Drug dealers are also highly regarded by other prisoners due to their economic resources, which can help corrupt guards and finance escapes more easily.

${ }^{8}$ The main information supplied by squealers is related to the arrangements carried out by inmates to make escapes and riots feasible as well as the information on individuals responsible for transporting drugs, weapons, cell phones and other forbidden objects or substances into the prison

${ }^{9}$ The facilities opened in 2001 (CPTF) and 2003 (CPV). In both prisons around $60 \%$ of the inmates are in for a maximum 8year stay. The majority were found guilty of crimes against others (murders, attacks etc.), followed closely by crimes against property (robbery, burglary etc.) and drug dealing crimes.

${ }^{10}$ The authors have conducted comparative research among three relatively similar correctional facilities in Louisiana - USA. One of them is managed by the state government and the other two by different private companies.

${ }^{11}$ Higher levels of state bureaucracy have the formal authority over several tasks undertaken by the prison director. However, information asymmetry is important enough to allocate the real authority to the prison director (Aghion \& Tirole, 1997).

${ }^{12}$ An example of the reduction in information asymmetry is the fact that the private operator is obliged to send to the government bureaucrats copies of all payments related to the management of the correctional facility. This information can help government bureaucrats to estimate with a certain amount of precision the incurred costs of the private operator. This information can be used in future franchise biddings.

${ }^{13}$ In order to mitigate internal conflicts it is also necessary to understand what is going on inside the cells and galleries. That is why it is important to know the informal codes of inmates.

${ }^{14}$ As of late September, 2005, CPV held 311 inmates, 43 above capacity (Source: www.sjdh.ba.gov.br < Retrieved October, 18th 2005>).

${ }^{15}$ In fact, compared to the publicly operated facility, the privately operated prison has 3 times more inmates released or given parole or probation.

${ }^{16}$ The difficulties in terminating the contracts of civil servants are directly responsible for the higher levels of absenteeism in the public prison. Since the probability of being punished is lower in comparison to the hybrid governance, the civil servants may have additional incentives to collude with inmates or to behave violently. Very often, there is evidence of correctional officers' misconduct when having direct contact with inmates.

${ }^{17}$ On the other hand, the tacit knowledge accumulated by correctional officers, who know a great deal about their ploys, can also hinder monitoring by mangers. This fact is an additional explanation for the recruiting of squealers among the prisoners.

${ }^{18}$ In the case of $\mathrm{CPV}$, some complaints of torture against the inmates were raised by an NGO. The Humans Right Commission of Bahia State Congress subsequently carried out an investigation. After an independent investigation, the commission detected no abuse. In contrast at the CPTF in 2002 a federal commission confirmed the practice of torture on 14 inmates which resulted in the unit manager's dismissal. 


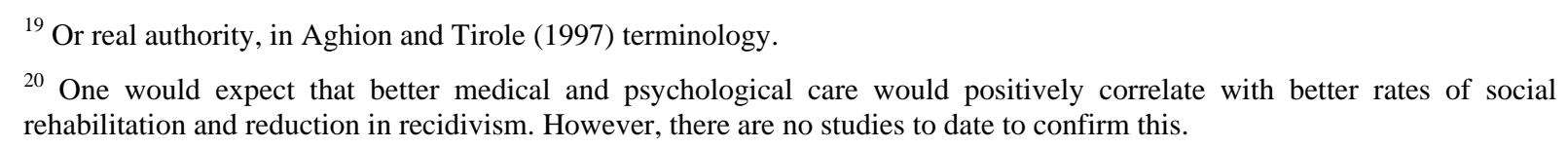

\section{REFERENCES}

Affonso, D. K. (2002). Privatização de presídios: terceirização dos serviços penitenciários. Dissertação de mestrado, Universidade de São Paulo, São Paulo, SP, Brasil.

Aghion, P., \& Tirole, J. (1997). Formal and real authority in organizations. Journal of Political Economy, 105(1), 1-29.

Araújo, J. M. (1995). Privatização das Prisões. São Paulo: Revista dos Tribunais.

Archeoembeault, W. G., \& Deis, D. R. (1996). Cost-effective comparisons of private versus public prisons in lousiana: a comprehensive analysis of allen, avoyelles ad winn correctional centers [Research paper]. Lousiana State University.

Arida, P., Bacha, E. L., \& Lara-Resende, A. (2005). Credit, interest, and jurisdictional uncertainty: conjectures on the case of Brazil. In F. Giavazzi \& I. Goldfajn (Eds.). Inflation targeting and debt: the case of Brazil. Cambridge, MA: MIT Press.

Azevedo, P. F., \& Silva, V. L. S. (2002). Contractual mix in Brazilian franchising [Working Paper]. Université de Paris I, Pantheon-Sorbonne, Paris.

Barzel, Y. (1997). Economic analysis of property rights (2nd ed.). Cambridge: Cambridge Univ. Press.

Bayer, P., \& Pozen, D. L. (2005). The effectiveness of juvenile correctional facilities: public versus private management. Journal of Law and Economics, 48, 549-589.

Becht, M., Bolton, P., \& Röell, A. (2002). Corporate governance and control [Working Paper Series $n^{\circ}$ 9371]. National Bureau of Economic Research.

Brickley, J. A., Coles, J. L., \& Jarrel, G. (1997). Leadership structure: separating the CEO and chairman of the board. Journal of Corporate Finance, 3(3), 189-220.

Cabral, S., \& Saussier, S. (2006). Are prisons good candidates for public and private agreements? evidences from Brazil, France and United States [Working Paper]. University of Paris I, Analyse Théorique des Organisations et des Marchés, Sorbonne.

Carvalho, E. (1998). A mácula do crime. Belo Horizonte: Ciências Jurídicas.

Cour des Comptes (2006, Janvier 28). Rapport public thématique: garde et reinsertion-la gestion de prisons. Paris: Leg Psy. Retrieved from http://www.psy-desir.com/leg/spip.php?article1278.

Departamento Penitenciário Nacional (2006). Relatório de gestão DEPEN: Exercício 2005. Brasil: Ministério da Justiça.

Dilulio, J. J., Jr. (1988). What's wrong with private prisons. Public Interest, (92), 66-83.

Dilulio, J. J., Jr. (1996). Help Wanted: Economists, Crimes and Public Policy. Journal of Economic Perspectives, 10(1), 3-24.

Direction de l'Administration Penitentiaire (2004). Les chiffres clés de l'administration pénitentiaire. Paris: Ministère de la Justice. 
Direction de l'Administration Penitentiaire (2005). Les chiffres clés de l'administration pénitentiaire. Paris: Ministère de la Justice.

D’Urso, L. F. B. (1996). A privatização dos presídios (Terceirização). Dissertação de mestrado, Faculdade de Direito, Universidade de São Paulo, São Paulo, SP, Brasil.

Guppy, P. (2003, February). Private prisons and the public interest: improving quality and reducing cost through competition. Seatle, WA: Washington Policy Center.

Hart, O. (1995). Firms contracts and financial structure. New York: Oxford University Press.

Hart, O. (2003). Incomplete contracts and public ownership: remarks and application to publicprivate-partnerships. Economic Journal, 113(486), C69-C76.

Hart, O., Shleifer, A., \& Vishny, R. W. (1997). The proper scope of government: theory and an application to prisons. Quarterly Journal of Economics, 112(4), 1127-1161.

HM Prison Service annual report and accounts april 2004-march 2005 (2005, July 19). London: The Stationery Office (Information and Publishing Solutions TSO).

Lazerges, C. (1997). Les établissements penitentiaires a gestion mixte: à l'eprouve de l'observation. In P. Lafarge (Ed.). Établissements penitentiaires a gestion mixte: actes du colloque de montpellier, 17 mars 1997. Paris: Pedone.

Lemgruber, J. (2000, Julho). O sistema penitenciário brasileiro. Anais do Encontro do Fórum de Debates sobre Criminalidade, Violência e Segurança Pública no Brasil, Rio de Janeiro, RJ, Brazil, 1.

Levy, B., \& Spiller, P. (1996). Regulations, institutions and commitment:comparative studies of telecommunications. Cambridge: Cambridge University Press.

Lukemeyer, A., \& McCorkle, R. (2006). Privatization of Prisons: Impact on Prisons Conditions. American Review of Public Administration, 36(2), 189-206.

National Audit Office (2003). The operational performance of PFI prisons. London: The stationery office.

Minhoto, L. D. (2000). Privatização de presídios e criminalidade: a gestão da violência no capitalismo global. São Paulo: Max Limonad.

Mitchell, M. (2003). The pros of privately-housed cons: new evidence on the cost savings of private prisons. New Mexico: Rio Grande Foundation.

Roth, L. (2004). Privatization of prisons. parliament of new south wales. Background [Paper $n^{0}$ 3/2004]. Retrieved December 09, 2005, from http://www.parliament.nsw.gov.au /prod/parlment/publications.nsf/.

Shirley, M., \& Ménard, C. (2002). Cities awash: a synthesis of the country cases. In M. Shirley (Ed.). Thirsting for efficiency: the economics and politics of urban water system reform (1-42). Oxford: Elsevier Science.

Harrison, P. M., \& Beck, A. J. (2005, October). Prisoners in 2004. Bureau of Justice Statistics Bulletin, (NCJ 210677), 1-14.

Varella, D. (1999). Estação carandiru. São Paulo: Cia. das Letras.

Viggiano, F. B. (2002). Endurecimento das penas e da execução penal: retrocesso inigualável. Revista de Informação Legislativa, (156) ano 39, 25-31. 
Wacquant, L. (2001). As prisões da miséria. Rio de Janeiro: Jorge Zahar Editor.

Williamson, O. (1985). The economic institutions of capitalism: firms, markets, relational contracting. New York: The Free Press.

Williamson, O. (1999). Public and private bureaucracies: a transaction cost economics perspective. Journal of Law, Economics and Organization, 15(1), 306-342.

Zylbersztajn, D., \& Nadali, L. B. (2003). Tomatoes and courts: strategies of the agro-industry facing weak contract enforcement. Proceedings of the Annual Conference of the International Society for New Institutional Economics, Budapest, Hungary, 7. 